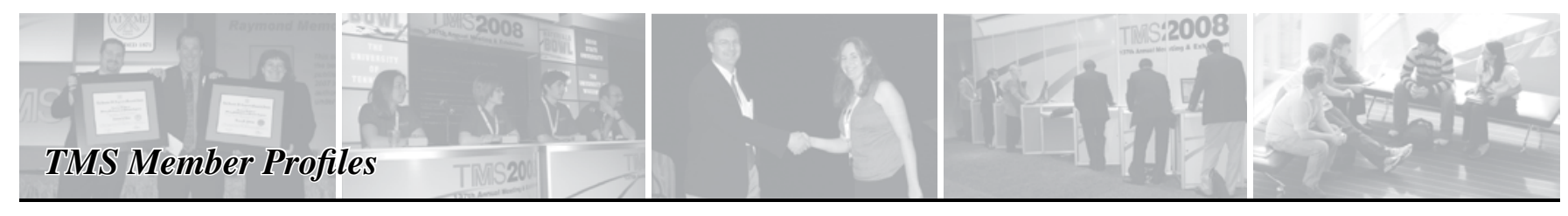

\title{
Meet a Member: Raymond Smith: Hazardous Abandoned Mine Finder
}

Editor's Note: This profile piece was submitted by Raymond Smith as a first-person account in response to a Meet a Member inquiry.

In a 10,000 square mile section of south central Arizona, it took 150 years for innumerable prospectors and miners to burrow over 6,000 holes, adits, and shafts into the hard, dry, desert mountain soil and rock. It was man's insatiable quest for gold, silver, and copper that drove him to face the scorching heat of summer days, the deep penetration of the night desert's chill, and the gripping loneliness shared only with the pick, shovel, and burro.

It has taken since 1989 for eight old men to seek out those thousands of mines and holes from maps and records. It has been their mission to erect safety signs, pin point their exact location with satellite positioning units, and record environmental data such as acid drainage and wildlife presence.

During the past 20 years, half of the original group has passed away. However, three are still at it-myself, Ray Smith, 92, retired president of Michigan Technological University; Don Blickede, 90, a metallurgist; and Carter Beach, the youngster at 87 , a chemical engineer. New men have been recruited to follow the enduring legacy of the Hazardous Abandoned Mine Finders-a Forest Service volunteer group skilled in the by-ways of the Arizona desert. To the young, we mine finders are truly old-but those same questioning youngsters might have difficulty following the old in their demanding scramble up the cactus and thorn-studded cliffs carrying metal posts, signs, hammers, drills, radios, global positioning system units, and, of course, an adequate supply of water.

So, each week we gather at the starting base, unfold oft-used and tattered maps, trace out the day's route, assign partnership teams, agree on meeting

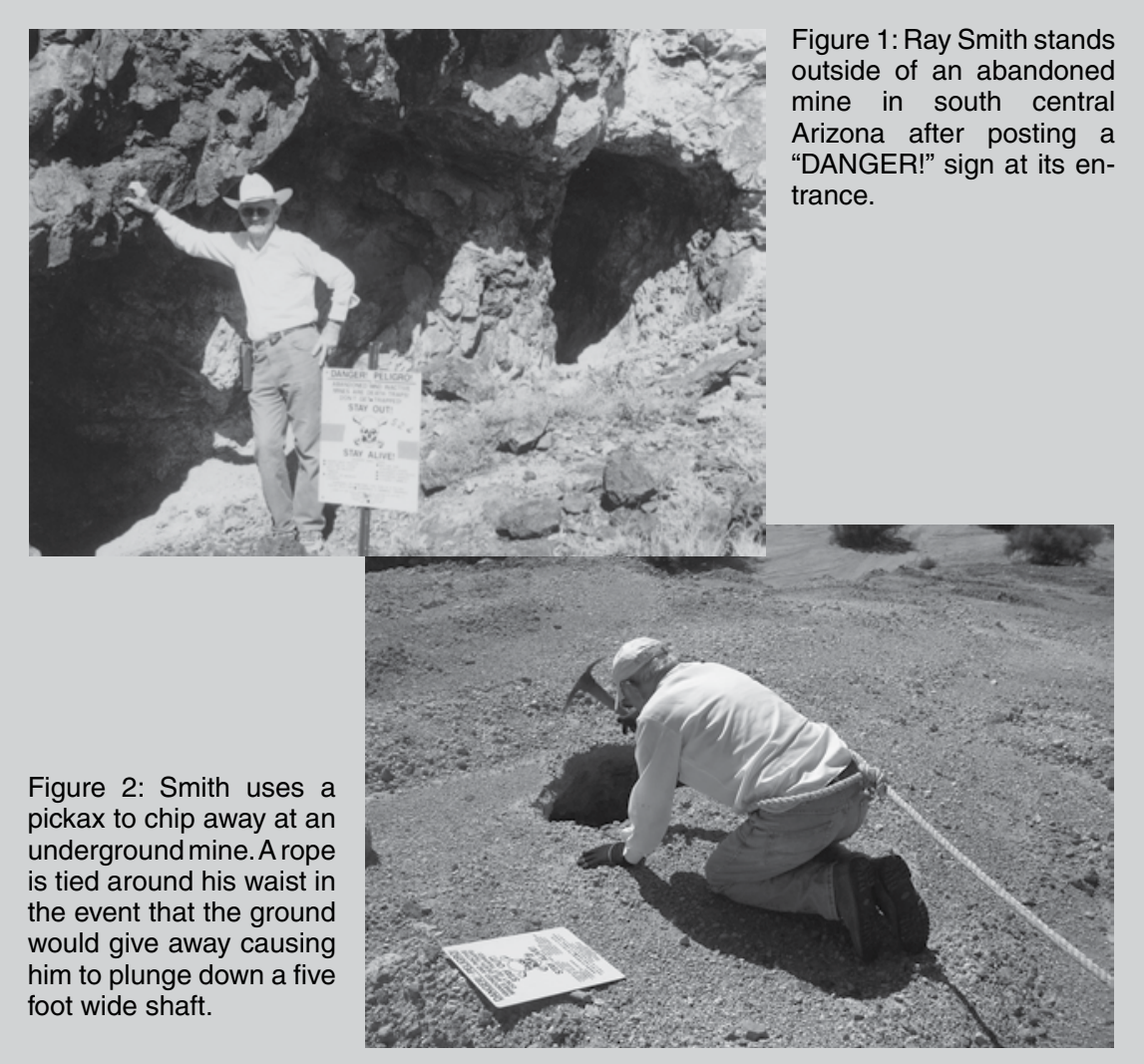

points, and then with a final check on our powerful portable radios pile onto four wheelers. A new day has started. A day that will titillate the senses, stimulate the curiosity, and then bring satisfaction as mine after mine reveals its hiding place. It will bring the gift of another day brimmed to the top with the good life and close companionship. We are the men who fight to draw on the bounties that nature has to offer and in the process strive to do our fellow man good by helping prevent the unwary from venturing into unsafe manbuilt adits and shafts where killer bees, rattlesnakes, scorpions, cougars, and bears may have taken refuge or where crumbling rock waits for the tremor of man's foot to break it loose. We are men of all walks of life with two things in common-love of the desert and mountains and an unbridled curiosity of the never ending quest for minerals. We find holes dug in desolate areas with no signs of mineralization and adits on cliffs where it would seem impossible to get ore to safe ground.

These old mines hold a thousand stories, some fact, some fancy; but the darkened adits, ominous deep shafts, twisted mine rails, and rusted equipment have their own stories. It is the unanswered story that tweaks that touch of prospector in the searcher so that you always look forward to another day in the mountains for more unmarked mines. Yet, even more precious to us than curiosity, physical exercise, and service to the State, is the enduring companionship and deep respect for each other that has been built in our years of searching for old mines.

In 1995, our group of searchers received the Governor's Award for our unique service. A year later, we were honored by the National Forest Service. But an important payoff is not these awards, but rather the stimulation of reliving and partially understanding the travails endured by the early miners and prospectors. 